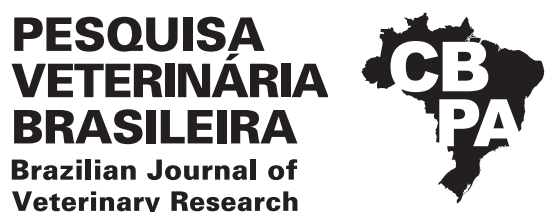

Pesq. Vet. Bras. 40(5):340-345, May 2020 DOI: 10.1590/1678-5150-PVB-6532

Original Article

Veterinarv Research

ISSN 0100-736X (Print)

Livestock Diseases

ISSN 1678-5150 (Online)

\title{
Pythiosis in cattle in Northeastern Brazil ${ }^{1}$
}

\author{
Lisanka A. Maia ${ }^{2}$, Erick P.F. Souto ${ }^{2 *}$ (D), Maria T.S. Frade ${ }^{2}$, Luciano A. Pimentel ${ }^{3}$, \\ Edisio O. Azevedo ${ }^{4}$, Glaucia D. Kommers ${ }^{5}$ (D), Franklin Riet-Correa ${ }^{2}$ (D) \\ and Antônio F.M. Dantas ${ }^{2}$
}

\begin{abstract}
Maia L.A., Souto E.P.F., Frade M.T.S., Pimentel L.A., Azevedo E.O., Kommers G.D., Riet-Correa F. \& Dantas A.F.M. 2020. Pythiosis in cattle in Northeastern Brazil. Pesquisa Veterinária Brasileira 40(5):340-345. Laboratório de Patologia Animal, Hospital Veterinário Universitário, Centro de Saúde e Tecnologia Rural, Universidade Federal de Campina Grande, Campus de Patos, Av. Universitária s/n, Bairro Santa Cecília, Patos, PB 58708-110, Brazil. E-mail: erickplatini@gmail.com

The epidemiological, clinical and pathological aspects of cutaneous pythiosis occurring in cattle from three farms in the Northeastern of Brazil are described. A biopsy of the lesions of one bovine from each farm was performed. In two cases, the affected cattle had contact with water accumulated in dams during the dry season in the semiarid region. Another case occurred in the coastal tropical region in cattle grazing around irrigation channels. Clinically, lesions were observed mainly on the skin of the thoracic and/or pelvic limbs, characterized by flat and irregular ulcerated areas or nodules of varying sizes, some with fistulous tracts penetrating deep into the subcutaneous tissue. In one case the regional lymph nodes were affected. Histologically, in all cases, pyogranulomatous dermatitis associated with negative hyphae images, in hematoxylin-eosin stained sections, were observed. In sections stained by Grocott methenamine silver, the hyphae measured 2-8 $\mu \mathrm{m}$ and had irregular ramifications and rare septations. Immunohistochemistry technique demonstrated strong immunolabeling for Pythium insidiosum. Pythiosis should be included in the differential diagnosis of dermatopathies in cattle in the Northeastern of Brazil.
\end{abstract}

INDEX TERMS: Pythiosis, Brazil, cattle diseases, pyogranulomatous dermatitis, oomycete.

RESUMO.- [Pitiose em bovinos no Nordeste do Brasil]. Descrevem-se os aspectos epidemiológicos, clínicos e patológicos da pitiose cutânea em bovinos de três propriedades do Nordeste do Brasil. Uma biópsia das lesões de um bovino de cada propriedade foi realizada. Em dois casos, os bovinos afetados tiveram acesso à água acumulada em açudes durante a estação

\footnotetext{
${ }^{1}$ Received on January 7, 2020.

Accepted on publication January 22, 2020.

${ }^{2}$ Laboratório de Patologia Animal, Hospital Veterinário Universitário, Centro de Saúde e Tecnologia Rural, Universidade Federal de Campina Grande (UFCG), Av. Universitária s/n, Bairro Santa Cecília, Patos, PB 58708-110, Brazil. *Corresponding author: erickplatini@gmail.com

${ }^{3}$ Agricultural, Environmental and Biological Science Center (AEBSC), Universidade Federal do Recôncavo da Bahia (UFRB), Cruz das Almas, BA 44380-000, Brazil.

${ }^{4}$ Departamento de Medicina Veterinária, Universidade Federal de Sergipe (UFS), Av. Marechal Rondon s/n, Jardim Rosa Elze, São Cristóvão, SE 49100-000, Brazil.

${ }^{5}$ Departamento de Patologia, Universidade Federal de Santa Maria (UFSM), Av. Roraima 1000, Cidade Universitária Bairro, Camobi, Santa Maria, RS 97105-900, Brazil.
}

seca da região semiárida. 0 outro bovino acometido estava a pastoreio próximo a canais de irrigação na região litorânea. Clinicamente, as lesões foram observadas principalmente na pele dos membros torácicos e/ou pélvicos e caracterizavamse por áreas planas e irregulares de ulceração ou nódulos de tamanhos variados, alguns com trajetos fistulosos penetrando profundamente no tecido subcutâneo. Em um caso, os linfonodos regionais foram afetados. Histologicamente, em todos os casos, observou-se dermatite piogranulomatosa associada a imagens negativas de hifas, em secções corados por hematoxilina e eosina. Em seções coradas por metenamina de prata de Grocott, as hifas mediam $2-8 \mu \mathrm{m}$ e possuíam ramificações irregulares com raras septações. A imuno-histoquímica demonstrou forte imunomarcação para Pythium insidiosum. A pitiose deve ser incluída como diagnóstico diferencial de dermatopatias de bovinos no Nordeste do Brasil.

TERMOS DE INDEXAÇÃO: Pitiose, bovinos, Brasil, doenças de bovinos, dermatite piogranulomatosa, oomiceto. 


\section{INTRODUCTION}

Pythiosis is caused by Pythium insidiosum, an aquatic oomycete of the kingdom Straminipila that affects several species of domestic animals, wild animals and man (Santurio et al. 2006, Gaastra et al. 2010). The occurrence of the disease is related to the contact of the animals with water containing mobile zoospores that constitute the infecting form of the agent (Santurio et al. 2006, Gaastra et al. 2010).

Pythiosis in cattle is considered infrequent and has been described in the United States (Miller et al. 1985), Venezuela (Pérez et al. 2005), Colombia (Cardona et al. 2012) and Brazil (Grecco et al. 2009, Santos et al. 2011). The low occurrence of the disease in this species has been attributed mainly to the spontaneous recovery of the lesions (Santurio et al. 1998, Grecco et al. 2009). In Brazil, although the disease occurs more frequently in horses, cases of pythiosis in cattle have been diagnosed in the Pantanal region (Santurio et al. 1998, Santos et al. 2011) and in the West (Gabriel et al. 2008) and South of Rio Grande do Sul (Grecco et al. 2009).

In a study on skin diseases in horses in the Northeastern of Brazil, pythiosis represented $24.38 \%$ of the cases studied (Pessoa et al. 2014). In addition, several clinical forms of the disease have also been diagnosed in sheep, including cutaneous (Tabosa et al. 2004), nasal (Portela et al. 2010) and digestive (Pessoa et al. 2012) forms. Cases of cutaneous pythiosis had also been reported in a goat (Do Carmo et al. 2015), in three mules (Tabosa et al. 1999, Pessoa et al. 2014), and recently in a donkey (Maia et al. 2016). However, there are no reports of the disease affecting cattle in this region. The objective of this study was to describe the epidemiological, clinical and pathological findings of pythiosis in cattle in the Northeastern region of Brazil.

\section{MATERIALS AND METHODS}

The information included in this study was obtained through visits to farms with suspected cases of cutaneous pythiosis in cattle. Epidemiological and clinical data were collected and skin biopsies were performed on one animal from each farm visited. Lymph node biopsy was also performed on a bovine.

The collected material was fixed in $10 \%$ buffered formalin, included in paraffin wax, cut at $4-6 \mathrm{~m} \mu$, and stained by hematoxylin and eosin (HE). For the morphotintorial characterization of hyphae selected sections were stained by Grocott's methenamine silver (GMS) and periodic acid of Schiff (PAS). The photographed images and the diameter of the hyphae were obtained through an Axio Scope A1 digital camera, Axio Cam MRc5, controlled by the software Zen 2012 (Carl Zeiss MicroImaging GmbH).

Immunohistochemistry (IHC) was performed for identification of the agent. The IHC protocol was performed according to Martins et al. (2012) using a polyclonal antibody (anti-Pythium insidiosum) produced in rabbits (Gabriel et al. 2008). Briefly, the primary antibody at a dilution of 1 in 1,000 was detected by use of streptavidin-biotinalkaline phosphatase complex and labelling was 'visualized' with Permanent Red (Dako, Glostrup, Denmark) as a substrate chromogen. We analyzed a previously confirmed positive control (equine cutaneous pythiosis) simultaneously with the tested samples. The negative control included tissue samples incubated with phosphate buffered saline instead of primary antibody.

\section{RESULTS}

Three cases of pythiosis were diagnosed in cattle in the Northeastern region of Brazil. The first occurred in November 2007, in the municipality of São Mamede, in the mesoregion of the Sertão of the State of Paraíba, with semi-arid climate. In this farm the herd was composed of 50 cattle and the disease was observed in only one animal. The herd was raised in semi-extensive regime, fed with elephant grass and had access to a weir pond.

The second case occurred in January 2014 in the municipality of Japaratuba, in the eastern mesoregion of the State of Sergipe, with a tropical sub-humid climate. The region is characterized by coastal vegetation and Atlantic forest. From a herd of 90 cattle, two animals had cutaneous lesions. The animals grazed in a low land area crossed by an irrigation channel draining water continuously. The area was flooded during the rainy season and was the only source of food. The owner mentioned that in previous years other cattle had similar skin lesions and recovered spontaneously.

The third case occurred in October 2014, in the municipality of Lavras da Mangabeira, in the mesoregion of the Center-South of the state of Ceará, with semi-arid climate. The affected animal belonged to a herd of 33 cattle and 9 horses. These animals were raised extensively in native pasture (caatinga) and had access to an area adjacent to a pond where the vegetation remained green throughout the year.

The cutaneous lesions presented different characteristics regarding the location, form of presentation and clinical evolution. In Bovine 1, multifocal nodules were observed in the cervical, tibial, metacarpal and gluteal regions. Most of these nodules presented ulcerated, irregular, reddish surface with raised edges (Fig.1A) and others were covered by skin or showed depressed and alopecic fistulous tracts in the skin. In the biopsies, the lesion affected the skin, the subcutaneous tissue and sometime infiltrated the adjacent musculature. The cut surface showed irregular yellowish and reddish areas, delimited by whitish, smooth and shiny tissue (Fig.1C). In addition to the cutaneous lesions, the superficial cervical and pre-crural lymph nodes were enlarged and at the cut showed multifocal coalescent yellow nodules interspersed with discrete reddish areas (Fig.1D).

In Bovine 2 and 3 , the lesions, measuring $8-15 \mathrm{~cm}$, were characterized by ulcerated areas, with slightly elevated irregular borders and slightly depressed, moist and reddish center (Fig.1B). Bovine 2 were located in the metacarpal region and in Bovine 3, in the humeral and tibial regions. In Bovine 3, ulcerated and parched areas with dark halodelimited borders were also observed. In the cut surface, these lesions were restricted to the epidermis and dermis and were characterized by a whitish, firm tissue with multifocal coalescent areas ranging from 0.5 to $1.0 \mathrm{~cm}$.

In all cases, no treatment was prescribed, but spontaneous regression of the lesions occurred in 7 months in Bovine 1, 1 month in Bovine 2 and 2 months in Bovine 3.

The microscopic lesions observed in all cases were similar, varying only in the intensity of the cellular or tissue response, and were characterized by ulcerative pyogranulomatous dermatitis associated with negative hyphae images (Fig.2A). In Bovine 1, a marked cellular inflammatory response extending from the superficial dermis to the deep dermis, subcutaneous tissue and adjacent musculature, with multifocal areas of 
necrosis, was observed. This inflammatory response was characterized by the presence of multinucleated giant cells, epithelioid macrophages, lymphocytes and plasma cells, as well as neutrophils and eosinophils associated with diffuse connective tissue proliferation. Multifocal areas of hemorrhage and mineralization were also observed. The lymph nodes showed similar pyogranulomas with negative images of hyphae in the cortex and medulla.

In Bovine 2 and 3 the lesion was observed mainly in the superficial dermis and was characterized by multifocal to coalescent pyogranulomas composed of central areas containing discrete neutrophils and degenerate eosinophils, surrounded by macrophages, epithelioid macrophages and multinucleated giant cells, peripherally delimited by fibrous connective tissue. Less conspicuous granulomas consisted mainly of epithelioid macrophages and few multinucleated giant cells.

In all cases, transverse and longitudinal hyphae, sometimes surrounded by radiated eosinophilic material forming Splendore-Hoeppli phenomenon, were observed inside some pyogranulomas and in giant cells cytoplasm (Fig.2A and 2B). In the sections impregnated by GMS, were observed hyphae
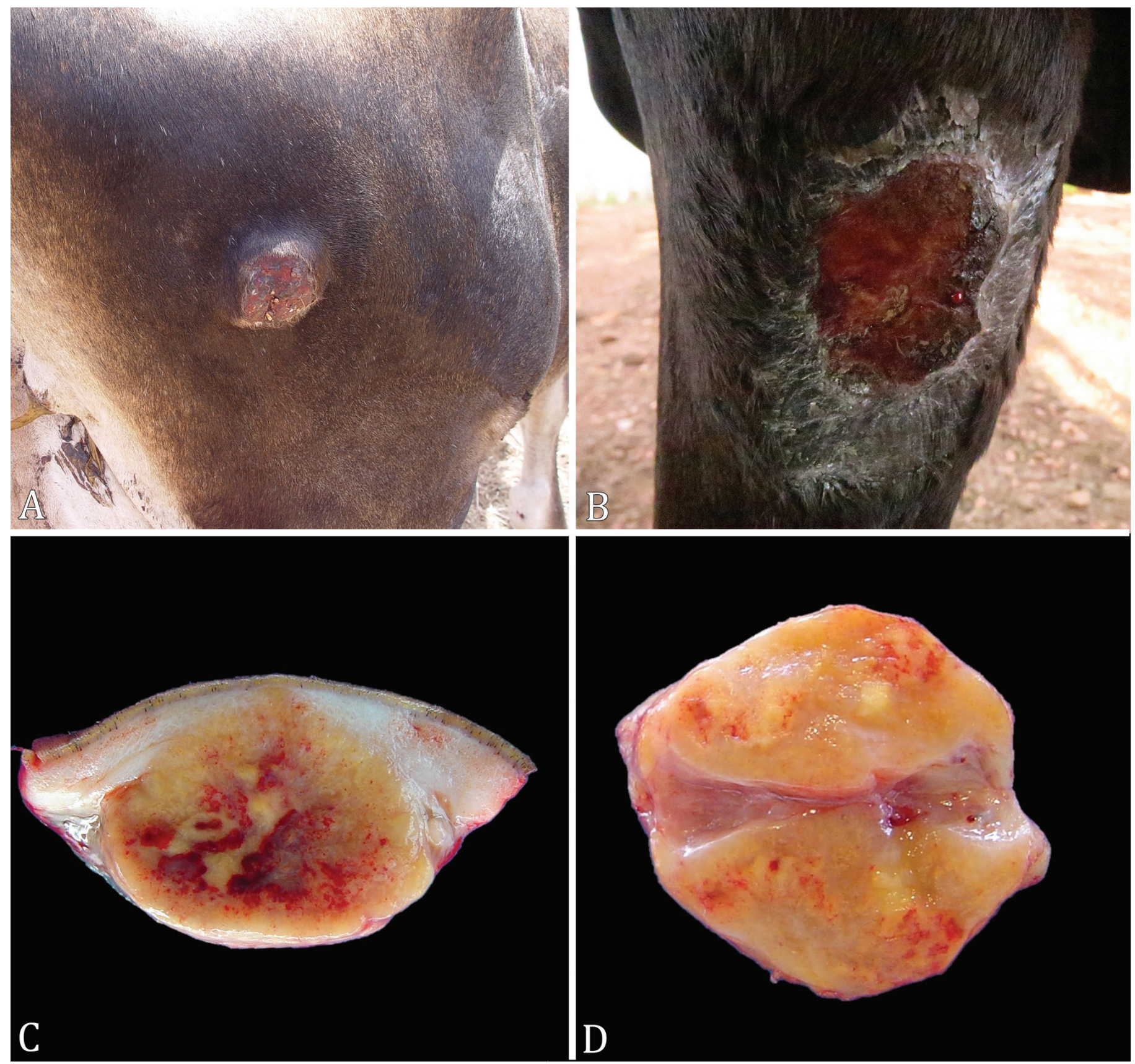

Fig.1. Pythiosis in cattle in Northeastern Brazil. (A) Skin, gluteal region. Nodular lesion with raised edges, and ulcerated, irregular, reddish surface. (B) Skin, humeral region. Ulcerated lesion with slightly elevated irregular borders, and depressed, moist and reddish center. (C) Nodular lesions, cut surface. Irregular yellowish and reddish areas delimited by whitish, smooth and shiny tissue. (D) Diffusely enlarged regional lymph node, cut surface. Multifocal to coalescent yellow nodules interspersed with discrete reddish areas. 
with a diameter varying from 2 to $8 \mu \mathrm{m}$ showing thick and parallel walls, with irregular ramifications and rare septations (Fig.2C). These hyphae were not stained by PAS and by IHC had strong immunolabeling for Pythium insidiosum (Fig.2D).

\section{DISCUSSION}

The diagnosis of pythiosis was made based on the epidemiological, clinical and pathological aspects, associated to the morphotintorial characteristics of the agent and the IHC. Although the three cases reported in this study occurred in the Northeastern region of Brazil, different epidemiological characteristics were observed according to the place of occurrence of the disease. Two cases occurred in semi-arid regions, from October to November, during the dry season, where the disease has been diagnosed in other species of animals, attributed to favorable environmental conditions and the scarcity of forage. The regional habit of maintaining water reserves, in the form of dams where the animals have access, especially during the dry season when pasture around these ponds stays green and the rest of the pasture is dry, favored the occurrence of the disease. In these conditions
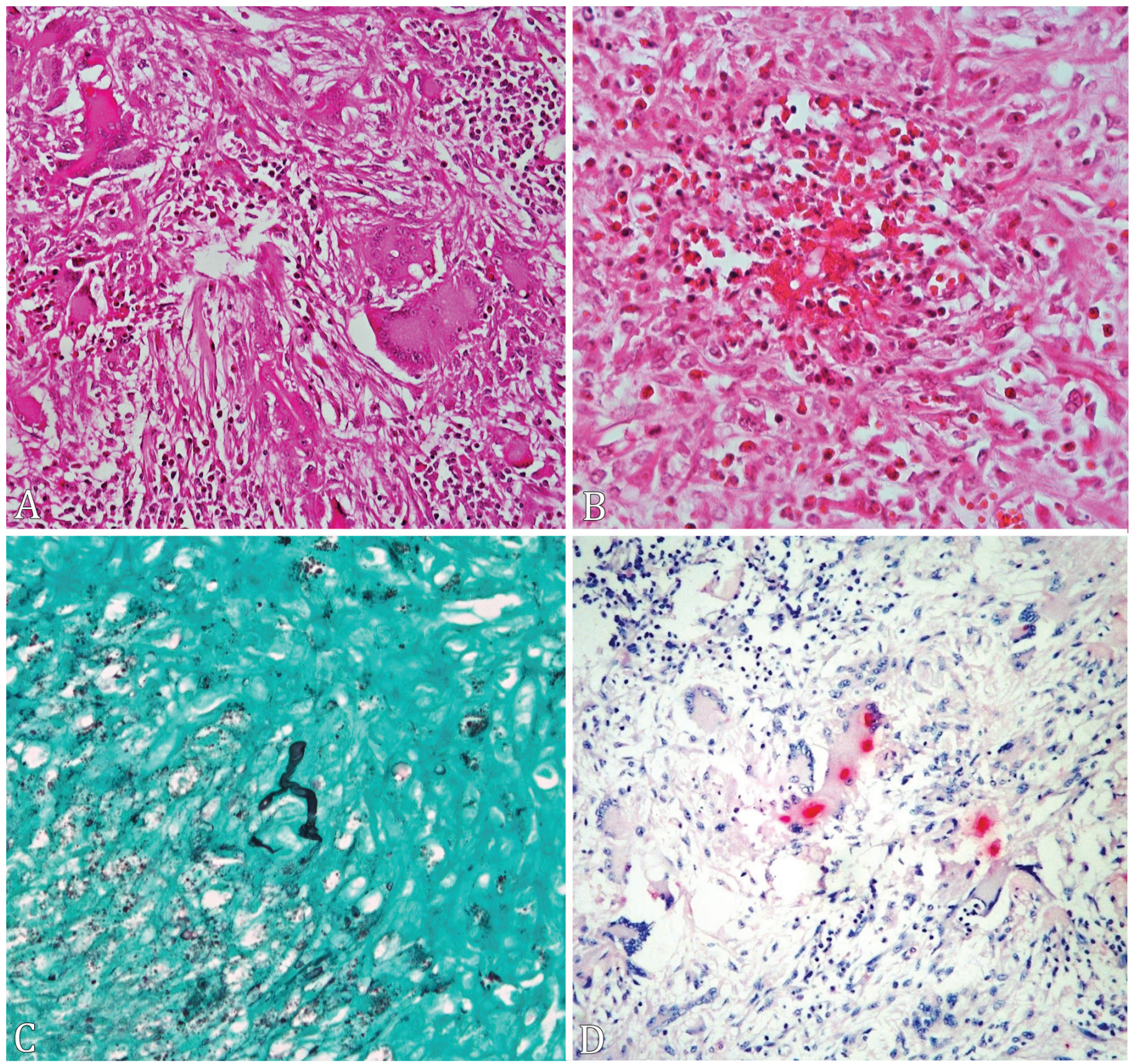

Fig.2. Pythiosis in cattle in Northeastern Brazil. (A) Skin. Pyogranulomatous dermatitis with numerous multinucleated giant cells and negative hyphae images in their cytoplasm (arrow). HE, bar $=100 \mu \mathrm{m}$. (B) Skin. Hyphae surrounded by Splendore-Hoeppli phenomenon. HE, bar $=50 \mu \mathrm{m}$. (C) Skin. Hyphae impregnated in black. GMS, bar $=50 \mu \mathrm{m}$. (D) Skin. Strong immunolabeling of hyphae in red for Pythium insidiosum. $\mathrm{IHC}$, bar $=50 \mu \mathrm{m}$. 
the animals should stay long periods in the shallow around the dams which are potential sources of infection by Pythium insidiosum (Tabosa et al. 2004, Pessoa et al. 2012, 2014).

The disease was also diagnosed in a region of humid coastal tropical climate of the Brazilian Northeastern, in an area flooded during the rainy season, crosses by an irrigation channel with running water for the all year. These environmental conditions differ from what is normally observed in the Northeastern region and resembles what has been described in other regions of Brazil (Gabriel et al. 2008, Grecco et al. 2009).

Recently, two outbreaks of bovine pythiosis were reported in the West and South regions of Rio Grande do Sul, affecting respectively 76 and 16 cattle that were placed in flooded pastures during the summer (Gabriel et al. 2008, Grecco et al. 2009). In the Western region of this state, pasture flooding was attributed to irrigation channels (Gabriel et al. 2008), while in the Southern region where equine pythiosis is endemic, it was associated with low fields and flat areas subject to frequent flooding during the rainy season (Grecco et al. 2009).

In the Brazilian Pantanal, the majority of pythiosis cases occur during the rainy season (February-May) when the region is flooded, in animals grazing on these native pastures with slow drainage, abundant aquatic vegetation and high temperatures (Santos et al. 2011). A similar situation was observed in Case 2, in the coastal region, in cattle grazing in flooded areas around and inside an irrigation channel which facilitates the contact of the skin with water at high temperatures. It is important to note that these epidemiological conditions had not been reported previously in Northeastern of Brazil, since all cases of pythiosis described in horses (Tabosa et al. 1999), sheep (Tabosa et al. 2004, Portela et al. 2010, Pessoa et al. 2012), goats (Do Carmo et al. 2015) and donkeys (Maia et al. 2016) occurred in the semi-arid region during the dry season in animals grazing in and around dams when there was shortage of forage in the pastures.

In two cattle, macroscopic lesions were similar to those described previously in this species (Santurio et al. 1998, Gabriel et al. 2008, Grecco et al. 2009, Santos et al. 2011). These lesions corresponded microscopically to the intense tissue response with a marked presence of fibroplasia, neovascularization and rare hyphae, and in these animals the clinical course of the disease was short with spontaneous healing of the lesions. However, attention was drawn to the characteristic of the lesion observed in Bovine 1, which were macroscopically nodular and sometimes infiltrated the subcutaneous and adjacent musculature, in addition to involvement of regional lymph nodes, characterizing metastasis.

Besides the nodular aspect, it was observed that the clinical course of the disease in this animal was longer, compared to the other animals in this study, as well as other reports in the literature (Santurio et al. 1998, Gabriel et al. 2008, Grecco et al., 2009, Santos et al. 2011). It is believed that the difference in the microscopic lesion characterized by an intense inflammatory response with marked presence of giant cells and hyphae and little tissue response, associated with the infiltrative character of the lesion and the longer clinical course may have contributed to the involvement of regional lymph nodes observed only in this animal, suggesting, apparently, an individual response.

The way one type of response overlaps and dominates the other in vivo is extremely complex and determined by several factors, including the type of antigen presenting cell (antigen presenting cell, APC), (dendritic cell versus macrophage and versus lymphocyte), the cytokine involved at the time of antigen presentation, which may be influenced by the nature of the pathogen or the antigen the regulation of cytokinedifferentiated T cells; the dose and affinity of the antigen for the $\mathrm{T}$ cell receptor; The timing and level of co-stimulatory signals expressed from both APC to T cell to T cell to APC during primary and secondary responses and the cessation of specific $\mathrm{T}$ and $\mathrm{B}$ responses through activation-induced cell death (Martins et al. 2012). This set of factors probably guides the different types of inflammatory response observed between the same species and between different species.

Dissemination of $P$. insidiosum to other organs has been reported, however is considered rare, and may occur hematogenously by direct extension of the lesions or by lymphatic route (Gaastra et al., 2010). It is possible that the lymph node metastasis observed in only one bovine had occurred via the lymphatic route, since only the superficial lymph nodes responsible for the drainage of the cutaneous lesion were affected. Metastases to regional lymph nodes have already been described in sheep (Tabosa et al. 2004) and horses (Miller \& Campbell 1984, Chaffin et al. 1995, Martins et al. 2012), but to date it was not reported in cattle.

Pythiosis in cattle is considered an infrequent disease. However, in studies that described the disease in cattle in Brazil, the authors report that the farmers are familiar with the disease and mentioned the occurrence of animals with similar disease in previous years and in neighboring properties (Pérez et al. 2005, Gabriel et al. 2008, Grecco et al. 2009, Santos et al. 2011). In this work, this fact was also reported in two of the farms visited, suggesting that as in the South and Pantanal Matogrossense, in the Northeastern region, pythiosis in cattle is underdiagnosed and occurs more frequently than reported. This is possibly associated with several factors, such as the spontaneous regression of the lesions, a short clinical course (when compared to equines), non-invasive lesions, and absence of systemic involvement. Due to these characteristics is possible that the farmers do not consult veterinary practitioners for the diagnosis and treatment of the disease.

\section{CONCLUSIONS}

Pythiosis in cattle occurs in a semi-arid and tropical coastal region of Northeastern Brazil, and should be included in the differential diagnosis of chronic infectious and neoplastic diseases affecting the skin of cattle.

The disease may present as an ulcerative and flat cutaneous lesion but also a nodular lesion with a prolonged course and in these cases the lymph nodes may be affected in addition to the skin.

Acknowledgements.- To the "Conselho Nacional de Desenvolvimento Científico e Tecnológico" (CNPq) for project financing: Universal Edict (Grant 474602/2012-5) and Productivity Scholarship (Grant 309460/2017-4).

Conflict of interest statement.- The authors report no conflicts of interest. The authors alone are responsible for the content and writing of the paper. 


\section{REFERENCES}

Cardona J.A., Vargas M. \& Perdomo S.C. 2012. Frecuencia de presentación de Pythiosis cutánea bovina (Pythium insidiosum) en tres explotaciones ganaderas de Córdoba, Colombia. Revta CES Med. Vet. Zootec. 7(2):47-54.

Chaffin M.K., Schumacher J. \& Mcmullan W.C. 1995. Cutaneous pythiosis in the horse. Vet. Clin. N. Am., Equine Pract 11(1):91-103. <http://dx.doi.org/10.1016/S0749-0739(17)30334-6>

Do Carmo P.M., Portela R.A., Silva T.R., Oliveira-Filho J.C. \& Riet-Correa F. 2015. Cutaneous pythiosis in a goat. J. Comp. Pathol. 152(2/3):103-105. <http://dx.doi.org/10.1016/j.jcpa.2014.11.005><PMid:25555632>

Gaastra W., Lipman L.J.A., De Cock A.W.A.M., Exel T.K., Pegge R.B.G., Scheurwater J., Vilela R. \& Mendoza L. 2010. Pythium insidiosum: an overview. Vet. Microbiol.146(1/2):1-16.<http://dx.doi.org/10.1016/j.vetmic.2010.07.019>

Gabriel A.L., Kommers G.D., Trost M.E., Barros C.S.L., Pereira D.B., Schwendler S.E. \& Santurio J.M. 2008. Surto de pitiose cutânea em bovinos. Pesq. Vet. Bras. 28(12):583-587.<http://dx.doi.org/10.1590/S0100-736X2008001200003>

Grecco F.B., Schild A.L., Quevedo P., Assis-Brasil N.D., Kommers G.D., MarcolongoPereira C. \& Soares M.P. 2009. Cutaneous pythiosis in cattle in the Southern region of Rio Grande do Sul, Brazil. Pesq. Vet. Bras. 29(11):938-942. <http://dx.doi.org/10.1590/S0100-736X2009001100013>

Maia L.A., Olinda R.G., Araujo T.F., Firmino P.R., Nakazato L., Miranda Neto E.G., Riet-Correa F. \& Dantas A.F.M. 2016. Cutaneous pythiosis in a donkey (Equus asinus) in Brazil. J. Vet. Diag. Invest. 28(4):436-439. <http://dx.doi.org/10.1177/1040638716651467> <PMid:27271986>

Martins T.B., Kommers G.D., Trost M.E., Inkelmann M.A., Fighera R.A. \& Schild A.L.A. 2012. Comparative study of the histopathology and immunohistochemistry of pythiosis in horses, dogs and cattle. J. Comp. Pathol. 146(2/3):122-131. <http://dx.doi.org/10.1016/j.jcpa.2011.06.006><PMid:21824626>

Miller R.I. \& Campbell R.S.F. 1984. The comparative pathology of equine cutaneous phycomycosis. Vet. Pathol. 21(3):325-332. <http://dx.doi. org/10.1177/030098588402100310> <PMid:6730223>
Miller R.I., Olcott B.M. \& Archer M. 1985. Cutaneous pythiosis in beef calves J. Am. Vet. Med. Assoc. 186(9):984-986. <PMid:3997656>

Pérez R.C., Luis-Leon J.J., Vivas J.L. \& Mendoza L. 2005. Epizootic cutaneous pythiosis in beef calves. Vet. Microbiol. 109(1/2)):121-128. <http://dx.doi. org/10.1016/j.vetmic.2005.04.020 > <PMid:15961262>

Pessoa A.F.A., Pessoa C.R.M., Miranda Neto E.G., Dantas A.F.M. \& Riet-Correa F. 2014. Doenças de pele em equídeos no semiárido brasileiro. Pesq. Vet. Bras. 34(8):743-748. <http://dx.doi.org/10.1590/S0100-736X2014000800006>

Pessoa C.R.M., Riet-Correa F., Pimentel L.A., Garino Jr F., Dantas A.F.M., Kommers G.D., Tabosa I.M. \& Reis-Júnior J.L. 2012. Pythiosis of the digestive tract in sheep. J. Vet. Diagn. Invest. 24(6):1133-1136. <http://dx.doi.org/10.1177/1040638712462026><PMid:23051827>

Portela R.A., Riet-Correa F., Garino J.F., Dantas A.F.M., Simões S.V.D. \& Silva S.M.S. 2010. Diseases of the nasal cavity of ruminants in Brazil. Pesq. Vet. Bras. 30(10):844-854.<http://dx.doi.org/10.1590/S0100-736X2010001000007>

Santos C.E.P., Santurio J.M. \& Marques L.C. 2011. Pitiose em animais de produção no Pantanal Matogrossense. Pesq. Vet. Bras. 31(12):1083-1089. <http://dx.doi.org/10.1590/S0100-736X2011001200008>

Santurio J.M., Alves S.H., Pereira D.B \& Argenta J.S. 2006. Pitiose: uma micose emergente. Acta Scient. Vet. 34(1):1-14. <http://dx.doi.org/10.22456/16799216.15060>

Santurio J.M., Monteiro A.B., Leal A.T., Kommers G.D., Sousa R.S. \& Catto J.B. 1998. Cutaneous Pythiosis insidiosi in calves from the Pantanal region of Brazil. Mycopathologia 141(3):123-125. <http://dx.doi. org/10.1023/a:1006995407665><PMid:9755503>

Tabosa I.M., Medeiros V.T., Dantas A.F.M., Azevedo E.O. \& Maia J.C. 1999. Pitiose cutânea em eqüinos no semi-árido da Paraíba. Arq. Bras. Med. Vet. Zootec. 51(1):27-30.

Tabosa I.M., Riet-Correa F., Nobre V.M.T., Azevedo E.O., Reis-Junior J.L. \& Medeiros R.M. 2004. Outbreaks of pythiosis in two flocks of sheep in northeastern Brazil. Vet. Pathol. 41(4):412-415. <http://dx.doi.org/10.1354/ vp.41-4-412><PMid:15232143> 